\title{
Studi Karakteristik Pembakaran Produk Hidrotermal Sampah Biomassa dan Sampah Plastik Jenis LDPE dalam Sub-Critical
}

\author{
Sri Gati Hutomo \\ Jurusan Teknik Mesin, Fakultas Teknik, Universitas Janabadra, Yogyakarta \\ E-mail: srigatihutomo@janabadra.ac.id
}

\begin{abstract}
Abstrak
Penelitian ini dimaksudkan untuk mengkaji karakteristik pembakaran produk arang yang dihasilkan dari proses hidrotermal sampah biomassa dan sampah plastik jenis LDPE dalam sub-critical water dengan berbagai kondisi operasi. Proses hidrotermal dilakukan dengan menggunakan Batch Type Reactor dengan pemanas utama uap air yang dihasilkan oleh mini boiler dan pemanas eksternal yang diperoleh gas burner sebagai pemanas sekunder. Kondisi operasi dari proses hidrotermal dirancang pada tekanan rendah, yakni 4 - 6 Bar dengan rentang temperatur berkisar $130-170{ }^{\circ} \mathrm{C}$. Parameter yang dikaji dalam penelitian ini adalah berat akhir produk arang, persentase pengurangan massa dan karakteristik pembakaran produk padat hasil proses hidrotermal yang mencakup temperatur maksimum nyala api, kestabilan api dan laju pembakaran. Hasil penelitian menunjukkan bahwa Proses hidrotermal sampah biomassa dan sampah plastik dapat dilakukan pada tekanan yang lebih rendah, hanya saja untuk mendapatkan kualitas produk yang lebih baik diperlukan temperatur yang lebih tinggi. Temperatur proses hidrotermal berpengaruh besar terhadap kualitas dan besarnya persentase berat produk akhir (arang). Semakin temperatur proses hidrotermal, maka besarnya persentase berat produk akhir padat (arang) akan semakin kecil diiringi kualitas produk yang semakin meningkat. Proses hidrotermal terhadap sampah biomassa dan sampah plastik dapat meningkatkan kandungan karbon dalam produk arang sehingga kualitas kedua sampah sebagai bahan bakar alternatif juga meningkat. Berdasarkan persentase berat dan kualitas produk akhir padat (arang), maka kondisi optimum proses hidrotermal yang dikaji diperoleh pada temperatur $155-160{ }^{\circ} \mathrm{C}$, tekanan 5- 6 Bar dengan waktu tahan 2 jam. Temperatur proses hidrotermal dan jenis sampah juga mempengaruhi karakteristik pembakaran produk arang yang dihasilkan oleh proses hidrotermal.
\end{abstract}

Kata Kunci: hidrothermal, temperatur, holding time, arang..

Abstract

This research is looking for combustion characteristics of charcoal products that produced from the hydrothermal process of biomass waste and LDPE type plastic waste in sub-critical water with various operating conditions. The hydrothermal process is carried out using a Batch Type Reactor with the main steam heater produced by a mini boiler and an external heater obtained by the gas burner as a secondary heater. The operating conditions of the hydrothermal process are designed at low pressure, which is 4-6 Bar with a temperature range of $130-170^{\circ} \mathrm{C}$. The parameters examined in this study were the final weight of the charcoal product, the percentage of mass reduction and the combustion characteristics of the solid product produced by the hydrothermal process which included the maximum temperature of the flame, the stability of the fire and the rate of combustion. The results showed that the hydrothermal process of biomass waste and plastic waste can be carried out at 
lower pressures, only to get better product quality higher temperatures are needed. The temperature of the hydrothermal process has a major effect on the quality and magnitude of the weight percentage of the final product (charcoal). The more the temperature of the hydrothermal process, the greater the percentage of the weight of the final solid product (charcoal) will be smaller accompanied by the increasing quality of the product. The hydrothermal process to biomass waste and plastic waste can increase carbon content in charcoal products so that the quality of both waste as an alternative fuel also increases. Based on the percentage of weight and quality of the solid product (char), the optimum conditions of the hydrothermal process studied were obtained at a temperature of $155-160^{\circ} \mathrm{C}$, a pressure of $5-6 \mathrm{Bar}$ with a holding time of 2 hours. The temperature of the hydrothermal process and the type of waste also affect the combustion characteristics of the charcoal product produced by the hydrothermal process.

Keywords: charcoal, holding time, hydrothermal, themperature.

\section{PENDAHULUAN}

Dalam laporan terbaru berjudul "What a Waste: A Global Review of Solid Waste Management" yang diterbitkan oleh Bank Dunia terungkap jumlah sampah padat di kota-kota dunia akan terus naik sebesar $70 \%$ tahun ini hingga tahun 2025 , dari 1,3 miliar ton per tahun menjadi 2,2 miliar ton per tahun. Mayoritas kenaikan terjadi di kota-kota di negara berkembang [1]. Dalam proses pengolahan sampah, proses hidrotermal adalah proses kimiawi untuk mengkonversi sampah organik menjadi karbon terstruktur dengan menggunakan air dengan tekanan dan temperatur tertentu. Proses ini juga dikenal dengan istilah karbonisasi hidrotermal. Metode ini merupakan metode baru dalam proses pengolahan sampah menjadi bioenergi. Kelebihan proses hidrotermal ini adalah dapat mengkonversi hingga 99\% karbon dalam senyawa organik menjadi karbon terstruktur atau sering dikenal dengan istilah biocoal. Keunggulan lainnya adalah produk akhir dari proses hidrotermal yang berupa karbon dapat dibuat dalam bentuk briket yang dapat digunakan sebagai bahan bakar yang ramah lingkungan karena menghasilkan karbondioksida netral [2][3].

Dari studi literatur yang telah dilakukan diketahui bahwa produk akhir yang dihasilkan dari proses hidrotermal sangat dipengaruhi oleh berbagai parameter diantarnya tempetatur dan tekanan air, waktu penahanan (holding time), jenis dan ukuran sampah [4]. Di samping itu berdasarkan hasil kajian diketahui bahwa beberapa penelitian yang telah dilakukan oleh beberapa peneliti sebelumnya umumnya melibatkan tekanan yang tinggi, yakni mencapai 24 bar bahkan ada 
yang mencapai 90 Bar sehingga sangat sulit untuk membuat pilot project pengolahan sampah menggunakan proses hidrotermal.

Oleh karena itu dalam penelitian ini permasalahan yang akan dikaji adalah bagaimana karakteristik pembakaran produk hidrotermal sampah biomassa dan sampah plastik jenis LDPE (low-density polyethylene) dalam sub-critical water dengan melibatkan tekanan yang lebih rendah, yakni 4- 6 Bar. Penelitian dilakukan dengan menggunakan model reaktor Batch dengan pemanas uap air yang dihasilkan oleh mini boiler. Pengembangan reaktor batch dilakukan menggunakan prototype yang telah dikembangkan oleh Fion [5].

\section{METODE PENELITIAN}

Dalam penelitian ini, sampah plastik yang digunakan adalah sampah plastik bekas minuman dan ban bekas kendaraan bermotor roda. Komposisi campuran sampah plastik dan ban bekas yang digunakan dalam penelitian adalah $1: 1$. Reaktor yang digunakan adalah model Batch dengan sumber panas utama dari uap air yang dihasilkan oleh mini boiler dan pemanas eksternal dari gas burner sebagai pemanas sekunder untuk menjaga kestabilan temperatur reaktor. Temperatur dan tekanan reaktor diatur pada rentang $(130-160){ }^{\circ} \mathrm{C}$ dan $(3-6)$ Bar. Rancangan instalasi penelitian dapat dilihat pada gambar 1 [6].

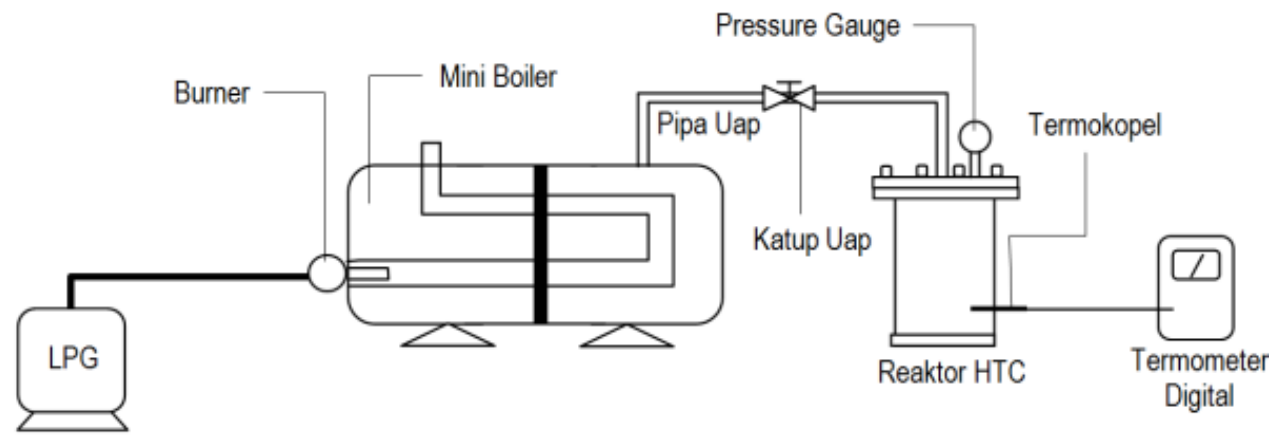

Gambar 1. Skema Rancangan Instalasi Peralatan

\section{HASIL DAN PEMBAHASAN}

Dari serangkaian pengujian proses hidrotermal yang telah dilakukan diperoleh hasil-hasil sebagai berikut [6]:

Studi Karakteristik Pembakaran Produk Hidrotermal Sampah Biomassa dan Sampah Plastik Jenis LDPE dalam Sub-Critical

(Sri Gati Hutomo) 


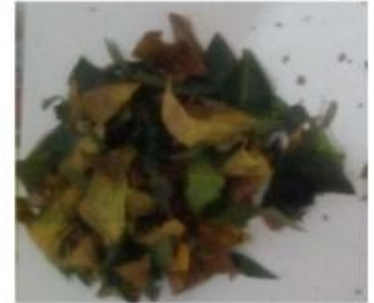

(a)

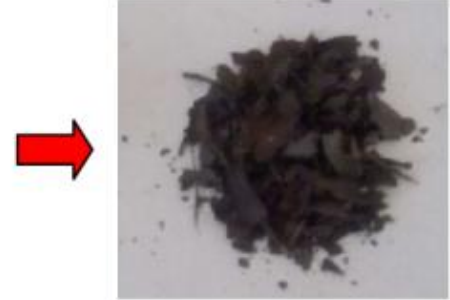

(b)

Gambar 2. (a) Sampah biomassa,

(b) hasil pada temperatur $130{ }^{\circ} \mathrm{C}$ dan waktu tahan 2 jam

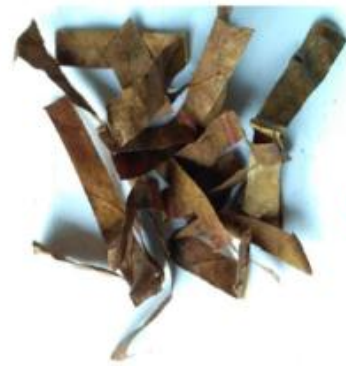

(a)

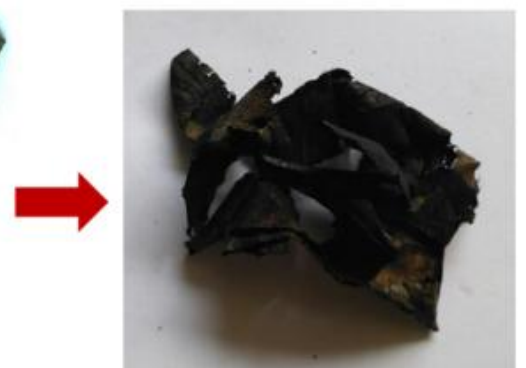

(b)

Gambar 3. (a) Sampah biomassa

(b) hasil pada temperatur $155^{\circ} \mathrm{C}$ dan waktu tahan 2 jam
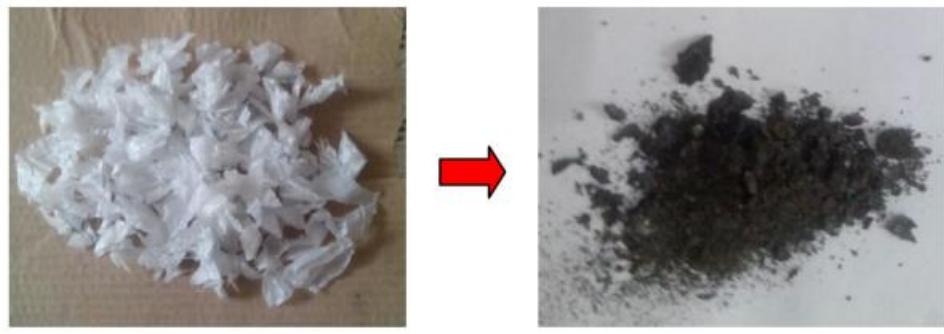

Gambar 4. Sampah plastik sebelum dan sesudah proses hidrotermal pada temperatur $155^{\circ} \mathrm{C}$ dan waktu tahan 2 jam

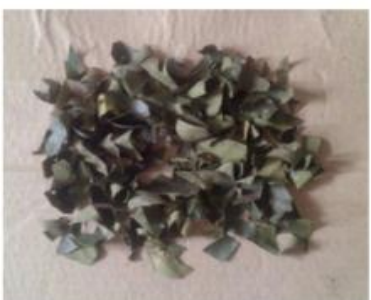

(a)

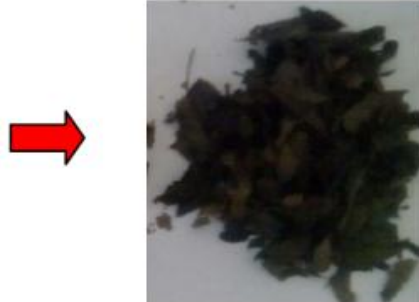

(b)

Gambar 5. Produk hasil hidrotermal campuran sampah biomassa dan plastik dengan komposisi 1 : 1 pada temperatur $155^{\circ} \mathrm{C}$ dan waktu tahan 2 jam 
Berdasarkan data-data yang diperoleh dari pengukuran berat massa sampel sampah plastik awal dan akhir setelah proses hidrotermal terhadap sampah plastik diperoleh :

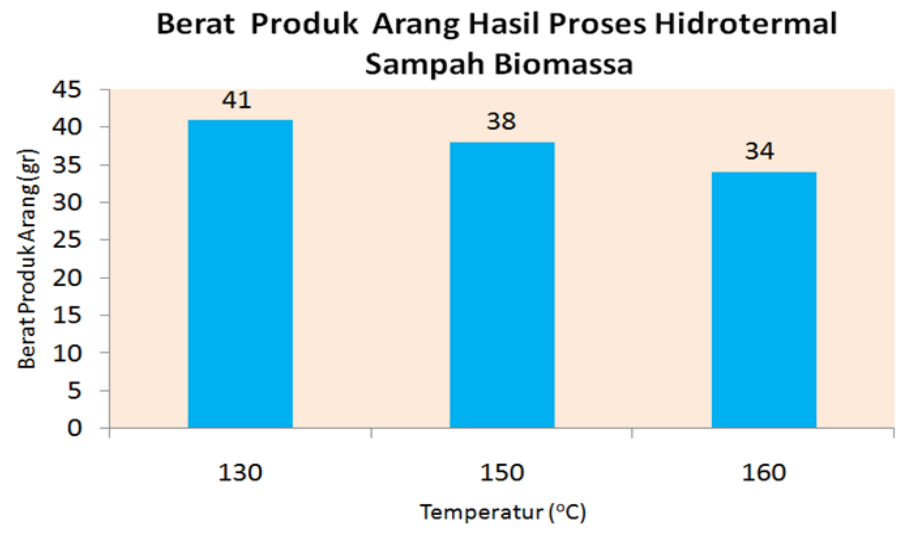

Gambar 6. Grafik berat produk arang terhadap temperatur

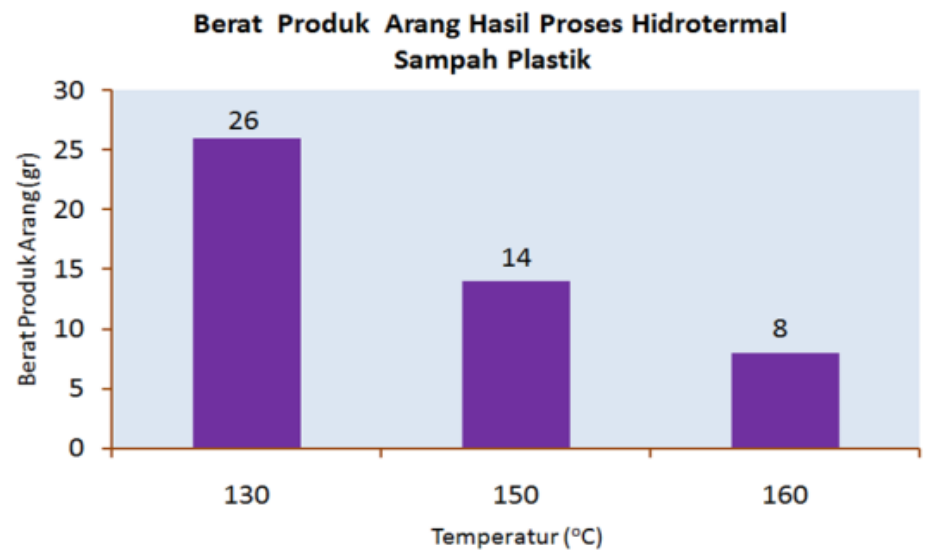

Gambar 7. Grafik berat produk arang terhadap temperatur

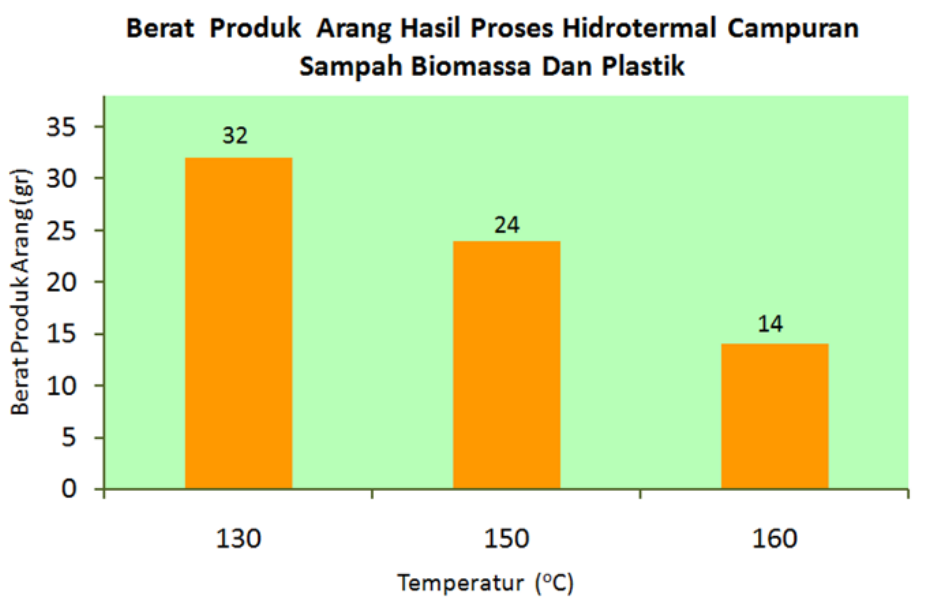

Gambar 8. Grafik berat produk arang proses hidrotermal campuran sampah biomassa dan plastik terhadap temperatur

Studi Karakteristik Pembakaran Produk Hidrotermal Sampah Biomassa dan Sampah Plastik Jenis LDPE dalam Sub-Critical

(Sri Gati Hutomo) 


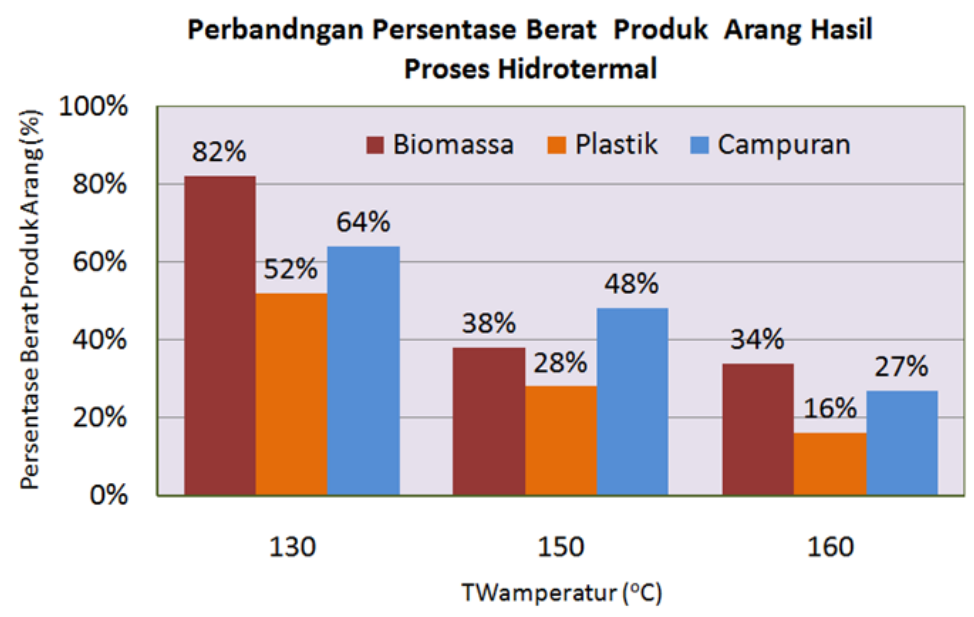

Gambar 9. Grafik perbandingan persentase produk arang sampah plastik ban bekas dan campuran sampah plastik-ban bekas

Berdasarkan hasil pengujian proses hidrotermal terhadap sampah biomassa, sampah plastik, dan campuran keduanya dapat diketahui bahwa secara umum proses hidrotermal karbonisasi (HTC) dapat mengubah sampah biomassa dan sampah plastik jenis LDPE menjadi produk arang (biochar) pada temperatur dan tekanan yang relatif rendah. Hanya saja, produk arang yang dihasilkan dari proses hidrotermal terhadap sampah biomassa, sampah plastik, dan campuran keduanya kualitasnya berbeda-beda tergantung kondisi operasi dari proses hidrotermal yang dijalankan dalam hal ini tergantung terhadap temperatur reaktor.

Berdasarkan pengamatan secara visual dapat diketahui bahwa semakin tinggi temperatur reaktor hidrotermal, maka kualitas hasil atau produk arang juga akan semakin baik. Hal ini dapat dilihat dari warna dan bentuk butiran dari produk arang yang dihasilkan dari proses hidrotermal. Kualitas terbaik diperoleh pada proses hidrotermal dengan temperatur $160{ }^{\circ} \mathrm{C}$, tekanan 6 Bar dan waktu tahan 2 jam.

Berdasarkan hasil pengujian seperti ditunjukkan oleh grafik pada gambar 7, 8 dan 9 dapat diketahui bahwa temperatur sangat berpengaruh pada pembentukan produk arang (residu karbon) pada proses hidrotermal semua sampah yang dikaji. Dalam hal ini semakin tinggi temperatur reaktor atau maka berat produk padat yang berupa arang akan semakin kecil. Hasil ini menunjukkan bahwa semakin tinggi temperatur reaktor, semakin banyak massa sampel yang terkonversi menjadi fraksi cair atau gas. Di samping itu, semakin tinggi temperatur reaktor 
hidrotermal memungkinkan produk padat yang terbentuk akan mengalami pemecahan menjadi fraksi cair dan gas sehingga berat produk adat akan semakin berkurang. Dalam penelitian ini, besarnya persentase berat akhir produk padat (arang) yang paling banyak diperoleh pada temperatur $130^{\circ} \mathrm{C}$ waktu tahan 2 jam, yakni mencapai $82 \%$ untuk sampah biomassa, 52\% untuk sampah ban bekas dan 64\% untuk campuran sampah plastik dan biomassa. Hanya pada kondisi ini produk akhir arang kualitasnya masih rendah karena belum semua material sampah terkoneversi menjadi arang.

Berdasarkan grafik yang ditunjukkan oleh gambar 9 dapat diketahui bahwa proses hidrotermal campuran sampah biomassa dan sampah plastik dapat menghasilkan produk akhir padat (arang) dengan kualitas yang lebih baik dari proses hidrotermal sampah biomassa dan sampah plastik secara individual untuk semua kondisi yang dikaji Hal ini dapat dilihat secara visual bentuk butiran dan warna dari produk arang yang dihasilkan dari proses hidrotermal campuran sampah plastik dan sampah ban bekas. Hasil ini menunjukkan bahwa terdapat efek sinergisitas antara sampah biomassa dan sampah plastik dalam pembentukan produk arang yang lebih berkualitas. Jika dilihat dari persentase berat akhir produk padat (arang) dari semua jenis sampah yang dikaji dapat diketahui bahwa pada kondisi operasi proses hidrotermal yang dikaji, persentase berat produk akhir proses hidrotermal sampah biomassa adalah yang paling besar diikuti oleh campuran sampah biomassa dan sampah plastik, kemudian yang paling kecil adalah sampah plastik. Tingginya persentase produk akhir proses hidrotermal dari sampah biomassa disebabkan karena pada temperatur yang relatif rendah, yakni $155^{\circ} \mathrm{C}$, proses konversi massa (pemutusan ikatan moleul) dari senyawa biomassa relatif lebih lambat sehingga menghasilkan produk akhir padat yang relatif lebih banyak.

Dari pengujian proses hidrotermal campuran sampah biomassa dan sampah plastik diketahui bahwa besarnya konversi massa yang terjadi lebih besar dari sampah plastik, tetapi lebih kecil dari sampah biomassa pada kondisi operasi yang sama, sehingga besarnya persentase berat produk akhir padat (arang) proses hirotermal campuran sampah biomassa-plastik lebih kecil dari sampah biomassa dan lebih besar dari sampah plastik. Hal ini menunjukkan bahwa terdapat efek 
sinergisitas antara sampah biomassa dan sampah plastik dalam pembentukan produk akhir padat (arang) jika dibandingkan dengan proses hidrotermal sampah plastik secara indvidual.

Dari hasil pengujian karakteristik pembakaran terhadap produk-produk proses hidrotermal diketahui bahwa produk arang hasil proses hidrotermal sampah biomassa dengan temperatur yang lebih tinggi menghasilkan laju pembakaran dan temperatur nyala api maksimum yang lebih tinggi. Hal ini menunjukkan bahwa temperatur proses hidrotermal dapat mempengaruhi karakteristik pembakaran produk, dalam hal ini semakin tinggi temperatur proses hidrotermal akan menghasilkan laju pembakaran dan temperatur nyala yang lebih tinggi. Hasil yang berbeda diperoleh dari proses pembakaran produk arang proses hidrotermal sampah plastik yang menghasilkan laju pembakaran dan temperatur ayala api yang lebih rendah dibandingkan dengan produk arang dari sampah biomassa, sedangkan untuk produk arang hasil proses hidrotermal campuran sampah biomassa-plastik menghasilkan laju pembakaran yang lebih rendah tetapi menghasilkan temperatur nyala api yang paling tinggi.

\section{SIMPULAN}

Berdasarkan hasil dan pembahasan penelitian proses hidrotermal sampah biomassa dan sampah plastik jenis LDPE, maka dapat disimpulkan hal-hal sebagai berikut :

a. Proses hidrotermal sampah biomassa dan sampah plastik dapat dilakukan pada tekanan yang lebih rendah, hanya saja untuk mendapatkan kualitas produk yang lebih baik diperlukan temperatur yang lebih tinggi.

b. Temperatur proses hidrotermal berpengaruh besar terhadap kualitas dan besarnya persentase berat produk akhir (arang). Semakin tinggi temperatur proses hidrotermal, maka besarnya persentase berat produk akhir padat (arang) akan semakin kecil diiringi kualitas produk yang semakin meningkat.

c. Proses hidrotermal terhadap sampah biomassa dan sampah plastik dapat meningkatkan kandungan karbon dalam produk arang sehingga kualitas kedua sampah sebagai bahan bakar alternatif juga meningkat.

d. Berdasarkan persentase berat dan kualitas produk akhir padat (arang), maka 
kondisi optimum proses hidrotermal yang dikaji diperoleh pada temperatur 130- $160{ }^{\circ} \mathrm{C}$, tekanan 5- 6 Bar dengan waktu tahan 2 jam.

\section{DAFTAR PUSTAKA}

[1] Anonim, 2012, Sampah Padat di Kota-kota Dunia Naik 70\%, http://www.hijauku.com, diakses pada 19 Juni 2017 jam 10.20.

[2] Husein, M.R., Marjuki, E.I., Iryawan, D., dan Hendrawati, T.Y. 2018. "Pengaruh Variasi Temperatur Pengolahan Hidrothermal Ampas Kopi terhadap Yield Energi untuk Bahan Baku Pembuatan Biobriket", Seminar Nasional Sains dan Teknologi 2018. Fakultas Teknik Universitas Muhammadiyah Jakarta, 17 Oktober 2018.

[3] Hoekman, S.K., Broch, A., Robbin, C., 2011, Hydrothermal Carbonization (HTC) of Lignocellulosic Biomass, Energi \& Fuels, 25(4), 1802-1810.

[4] Eriska, H., Dewi, K., Pasek, A.D. dan Damanhuri, E., 2016, "Hydrothermal Carbonization of Biomass Waste by Using a Stirred Reactor: An Initial Experimental Results", Jurnal Reaktor, Vol. 16, No. 4, Hal. 212-217, Universitas Diponegoro, Semarang, Indonesia.

[5] Fion, L., at. al, 2014, Hydrithermal Carbonization of Biomass : Design of a Batch Reactor and Preliminary Experimental Results, Chemical Engineering Transactions, Vol. 37, AIDIC Publication, Italy.

[6] Himawanto, D.A., Indarto, Saptoadi, H., Rohmat, T.A., 2010, "Pengaruh Heating Rate pada Proses Slow Pyrolisis Sampah Bambu dan Sampah Daun Pisang", Prosiding Seminar Rekayasa Kimia dan Proses, Jurusan Teknik Kimia Fakultas Teknik Universitas Diponegoro, Semarang. 